Kadri Asmer

\title{
THE DECADE OF GREAT MYTHS: DEVELOPMENTS ON THE ESTONIAN ART SCENE IN THE 1990s
}

The 1990s witnessed the total collapse of the political system in Eastern Europe, which directly influenced contemporary cultural structures: from the institutions and financing of the arts to the question of values that art should represent in the new circumstances. The decade in question is one of contradiction, destruction, and construction, and to regard it as a consistent entity is practically impossible. Therefore, social and cultural scientists have also preferred to approach it by stages, observing the democratisation processes step by step.

In the second half of the 1980s, the time of perestroika and singing revolution ${ }^{1}$, mass movements and protest waves started developing in Estonia, led by Estonian intellectuals and cultural elite, and based on ideas of nationalism and political freedom. The events of the singing revolution climaxed on 20 August 1991, as the Supreme Council of the Estonian SSR accepted the declaration of Estonia's national

1 The singing revolution refers to the socio-political events in the Baltic states in 19871991, which coincided with Mikhail Gorbachev's perestroika in the Soviet Union. The Singing Revolution is known as the non-violent revolution with rock concerts and Night Song Festivals at its core. The latter were instigated to publicly demand the restoration of Estonia's independence. The events culminated on 23 August 1989 with the Baltic Way - a peaceful demonstration involving people standing next to each other, holding hands, from Tallinn to Vilnius. 
independence. The communal events and actions leading to that were based on nationalist mentality and sense of unity, which within the Soviet cultural ideology functioned as hidden opposition as well as an encouraging force to send ever clearer messages to the central government in Moscow. However, the 1990s discarded the common goal and this led to an intensive move towards the free market economy, greater influences from the West, and a rethink of all spheres of society. Because of that, the period from 1991 onwards is referred to as an era of transitional culture, or it is identified as a period of absence of paradigms. ${ }^{2}$ In general, the 1990s have been described as the time of de-Sovietisation and construction of western-style institutions. ${ }^{3}$

This article will map out several developmental tendencies that began taking shape after the restoration of independence. To be sure, the transition from Soviet-style cultural politics to the liberal was not one-directional. Next to nationalism, the need to be fashionably western now came to the fore. On the one hand, people wanted fast internationalisation and successful liberalisation of different state structures, especially with regards to economic policies, but on the other hand the importance of traditions and national culture, which gravitate towards conservative values, were emphasized. In the western world today cultural liberalism rules, and to an extent we can note signs of assimilation: some conservative communities have appropriated phenomena belonging to mass or popular culture, and some previously radical-seeming art forms can safely be considered traditional today. Of course, conservativism is changing over time, constantly accepting previous negations, although its core beliefs remain unchanged. Here we could mention two of its unchanged positions: the superiority of tradition, and morals, which are seen as the foundations of national unity. Clearly, a cultural situation that challenges traditions will provoke opposition, and for a group of Estonian intellectuals it was like a nightmare come true in the 1990s, but retrospectively it was the normal flow of things. Estonian social scientist and politician Marju Lauristin has identified various values and attitudes related to the transitional culture in Estonia 'regarding success as the central value, having a mimetic relationship

2 Egge Kulbok-Lattik, "Eesti kultuuripoliitika ajaloolisest periodiseerimisest", Acta Historica Tallinnensia, 12 (2008), 120-144.

3 Ibidem, 127 with western ideals, overestimating economic growth as the sole aim of society's progress. ${ }^{\prime 4}$ Nonetheless, the changes in Estonian society in the 1990s were not location-specific, similar trends existed in all former republics of the Soviet Union. Therefore, the described developments are generally associated with the characteristics of a transitional culture and the metamorphoses occurring within it, which leads to new a) political; b) economic; c) cultural and national identity. ${ }^{5}$

In Estonia the changes were welcomed with great freedom-induced euphoria, but this was soon followed by the acknowledgement that the new democratic order was no longer based on one particular idea of national culture which would be common to all members of society, on the contrary - it favoured and deepened cultural differences. The latter started constructing a world view where instead of the nation centre stage belonged to individualism and everybody's personal world, which in light of liberalism and capitalism was now easier than ever to construct according to private dreams: 'Estonian transitional culture has taken us back to the previously yearned-for West. /---/ This process occurred in conjunction with globalisation, so that both played their part in all of the changes: technology, demographics, values, symbolic communications, consumption, lifestyle, behavioural patterns, etc. Values became increasingly individualist and hedonistic; personal success, self-presentation and openness became important.' How and whether this was reflected in art practices? To jump ahead and put it bluntly we could say that they acted first, and thought second.

Estonian cultural historian Marek Tamm has succinctly noted that 'nations are not born; they are made. ${ }^{7}$ In a situation where a state does not yet have a comprehensive political system or a unified

4 Marju Lauristin, "Eestlaste kultuurisuhte muutused liikumisel siirdeühiskonnas 4 Mã University of Tartu Press, 2012), 13.

5 Mikko Lagerspetz, "Estonian Identity Entering the Post-Modern World: the Role of National Culture", Management of Change: Cultural Aspects of European Enlargement and the Enlargement of the EU (Graz: KulturKontakt, 1998), 55-59.

6 Indrek Tart, Marko Sõmer, Laur Lilleoja, "Alusväärtused Eestis teise laine perioodil", Nullindate kultuur I: teise laine tulemine, comp. by Aili Aarelaid-Tart (Tartu: Tartu Ülikooli Kirjastus, 2012), 50

7 Marek Tamm, "How Are Nations Made?", The State is not a Work of Art, ed. by Katerina Gregos (Tallinn: Lugemik, 2018), 137. 
understanding of their national culture, fragmentation and potential divisions of value categories are inevitable - plurality of opinion is one of the hallmarks of a liberal society, but when that is the basis for construction of a new, common cultural sphere, it will most certainly lead to a cluster of contradictions. In the beginning of the 1990s there were as many differing opinions and interpretations of the meaning of culture, as there were oppositions and tensions, which rendered any clear definitions impossible. It is possible that this is why to this day there is no concrete definition of 'Estonian culture', and any talk of Estonian national culture is often outright avoided, as it would lead the researcher to the term 'nationalism'. ${ }^{8}$

This article studies the 1990s on the Estonian art scene primarily through material by local writers, especially texts written during the period in question. The main reason for that is that western art critics at the time knew relatively little about their contemporary art behind the Iron Curtain, which often caused misunderstandings in the 1990s. Eastern Europe was regarded with the curiosity of an explorer - as the American philosopher Noam Chomsky admitted, 'I think the prospects are quite dim for Eastern Europe. The West has a plan for it - they want to turn large parts of it into a new, easily exploitable part of the Third World. There used to be a sort of colonial relationship between Western and Eastern Europe; in fact, the Russians' blocking of that relationship was one of the reasons for the Cold War. Now it's being re-established, and there's a serious conflict over who's going to win the race for robbery and exploitation. ${ }^{\prime 9}$

Given this background, it is understandable why in some circles in Estonia people believed that the flourishing local idiosyncrasies and decentralisation in conjunction with cosmopolitan mass culture might weaken people's sense of national belonging. This refers to the process of voluntary acceptance of the so-called colonisers' values, traditions, and cultural models, and the alteration of one's own culture according to that of the colonisers..$^{10}$ Of course, it is dubitable whether we can speak of colonisation when there were not that many options on the table. As art historian Jaak Kangilaski asked in 1998 'do we want to be a small nation state of the North, or an overseas

8 Tõnu Viik, "Eesti kultuuri võimatu mõiste", Tuna, 2 (2012), 3.

9 Noam Chomsky, What Uncle Sam Really Wants (Berkeley, CA: Odonian Press, 1992), 71.

10 Tiit Hennoste, “Postkolonialism ja Eesti. Väga väike leksikon”, Vikerkaar, 4-5 (2003), 88-89. state of the USA?'11 With hindsight we can say that the path that was chosen seemed the most attractive, alluring and freedom-heralding at the time - a bumpy middle road between the two worlds.

\section{CHANGES IN ART POLICIES}

Estonian art scene of the 1990s was developing in the circumstances where one system had stopped existing before the next could start functioning. There were problems both within institutions and their management, the new times were causing confusion and lack of confidence. The changes that occurred at the turn of the 1990s raised more questions than answers. First, the state financing through the Ministry of Culture and the Artists' Association stopped, and the direct buys on which most artists had lived were discontinued. As there were no independent art galleries yet, the artists' financial circumstances worsened considerably, as did their statuses in the art world. Indeed, in the new situation the old luminaries were denied public appearances, because who had been famous in the Soviet cultural sphere could not be that in the new times, it seemed.

The first years of the 1990s were undoubtedly difficult and confusing - a functioning state did not exist yet; the main focus was on getting the economy in order, while at the same time culture was in urgent need of financial support. That environment was not sustainable for artists individually nor for professional arts in general. Partial state funding of cultural institutions did continue even during that period, but only to a minimal extent. Transitional processes were moving slowly and the Estonian Cultural Endowment law $^{12}$ which guaranteed regular support for culture was passed in 1994. Here we may note a few tendencies characteristic of transitional culture, such as inconsistent cultural legislation, unfair allocation of government subsidies, liquidation and sale of former Soviet cultural buildings, loss of prestige of government-supported culture and the

11 Jaak Kangilaski, "Eesti kultuuripoliitika vastandlikud ülesanded", Sirp, 05.06.1998.

12 Cultural Endowment of Estonia was first legally established on 5 February 1925. Efforts were made to continue its activities even during the Soviet government but without success. Officially, the Cultural Endowment was abolished on 24 April 941. It was reinstated in the re-independent Republic of Estonia on 1 June 1994 See Jüri Uljas, "Kultuurkapitali uus tulemine", Sirp, 24.07.2009. 
influx of commercial culture, etc. ${ }^{13}$ Lauristin has noted that while the onslaught of market mechanisms on media and culture divided the cultural audience, it also lowered the creators' position in society as intellectual leaders of people. While in the Soviet period and during the freedom movement of the late 1980s local intellectuals went from 'cultural heroes to the leaders of intellectual opposition', in the 1990s the old cultural strata were demolished, and 'artists and writers, favourite actors doing commercials and light entertainment shows, became the prisoners of market relations.'14 Behind Lauristin's harsh observation there lies a nod to the fact that many previous value and taste standards expired in the beginning of the 1990s, and it felt as though everything that had gone before the transition belonged to the dark corners of history.

The meaning and role of art became a separate issue in its own right - which goals and values should it carry in the new, free world? The Soviet occupation as the enemy had for a long time held the artists together, and losing it brought along a multitude of different ideas and opinions regarding the place of the artist in the new circumstances: what will art be like in the independent nation state, etc. Art historian Ants Juske has remarked that one of the more prevailing problems in the 1990s was the absence of an all-encompassing and common ideology - something which the artists had been used to earlier: 'Now that the time of national ideology is coming to an end, our cultural elite is in the grips of "worry ideology". /---/ The same ancient attitude that we absolutely must have an ideology that unifies our culture or the nation. ${ }^{15}$

Western intellectuals, mostly left-leaning, have pointed out that the 1990s had devastating impacts on the quality of culture, and not only in the context of Eastern Europe. For example, Chin-Tao Wu, art historian mainly focused on the Anglo-American cultural space, stated at the end of the 1990s that 'never before has the corporate world in America and Britain exercised such swat over high culture, in which business involvement had previously been thought of as

13 Kulbok-Lattik, "Eesti kultuuripoliitika ajaloolisest periodiseerimisest", 140.

14 Marju Lauristin, "Eestlaste kultuurisuhte muutused liikumisel siirdeühiskonnas võrguühiskonda", Nullindate kultuur I: teise laine tulemine, comp. by Aili Aarelaid-Tart (Tartu: Tartu Ülikooli Kirjastus, 2012), 20.

15 Ants Juske, "Mure-ideoloogia”, Looming, 4 (1994), 559-560. inappropriate, if not completely alien. ${ }^{16}$ Professor David Hawkes from USA has agreed with the latter, adding, 'this influence is particularly glaring in the visual arts, where patrons such as Charles Saatchi astutely perceive the ideological usefulness of aesthetic radicals like Damien Hirst. ${ }^{17}$ Similarly pessimistic assessments were expressed decades earlier by some more sternly traditionalist art theorists such as the godfather of neoconservatives ${ }^{18}$ - journalist Irving Kristol, who declared that 'the real disasters in life begin when you get what you want'. With this he meant that the age-old struggles and demands of liberal thinkers and intellectuals to keep all kinds of state censorship away from culture have now yielded quite unexpected results: 'They wanted a world in which Eugene O'Neill's Desire Under the Elms could be produced, or James Joyce's Ulysses published, without interference. They got that, of course; but they also got a world in which homosexual rape is simulated on stage, in which the public flocks to witness professional fornication, in which New York's Times Square has become a hideous marketplace for printed filth. ${ }^{19}$

The social and protest movements that led to the restoration of independence in Estonia are comparable to the processes in the USA in the 1980s - the so-called culture wars. ${ }^{20} 1960-1990$ in the USA saw the intensification of attitudes based on liberalism and neo-leftist views, whose goal was to reform social norms and to express dissatisfaction with the state's internal and external politics. In the latter half of the 1960s, anti-war and civil rights mass movements were born, at first on university campuses, then spreading throughout the whole society, including minorities. These debates, that climaxed in the 1980-1990s, were mainly focused on bringing feminism, homosexuality, AIDS awareness, anti-racism, and multiculturalism etc. to the cultural

16 Chin-Tao Wu, "Embracing the Enterprise Culture: Art Institutions Since the 1980s", New Left Review, 1/230 (1998), 28.

17 David Hawkes, Ideology (New York, London: Routledge, 2003), 12.

18 Neoconservatism is generally considered the more liberal version of conservatism, which means that opinions have always differed between neoconservatives and traditional conservatives, especially with regard to international issues; in terms of culture, their views follow similar sets of values.

19 Irving Kristol, "Pornography, Obscenity and the Case for Censorship", The New York Times Magazine, 28.03.1971, SM24.

20 The term 'culture war' comes from the German language (Kulturkampf) from the end of the $19^{\text {th }}$ century when it was used to signify efforts by chancellor Otto von Bismarck to unite different German principalities into a naty enfore Struggle to Define America (New York: BasicBooks, 1991), xii. 
arena. Therefore, the modern culture wars have been mostly defined as the culmination of the social changes, movements, and social policy debates in the USA. In principle, it meant conflicts between ideologically opposite groups which stemmed from different beliefs, philosophies, and cultural values. Amid the tension, different sides tried to define norms, or ways in which people should think and behave, and what actually is good, or bad. Art provided an outlet for that - it allowed to express and visualise social pain points; and in turn it became an easy target for attacks and critique.

We can draw parallels between the aforementioned and events behind the Iron Curtain: transition to the postmodern cultural environment brought with it a shift in art appreciation, accompanied by questions about the line between art and non-art, the marginalisation of ethical and aesthetic values, and the meaning of creative freedom and censorship. The conflicts that escalated in Estonia by the mid-1990s have in hindsight been some of the most intense and, to an extent, to this day unsolved debates around the fundamental and aesthetic preconditions of art.

The radicalisation of arts was opposed by the more traditionalist art historians and artists, who may be regarded as moderate conservatives. Among them we can include those that did not dispute (post)modernism, but did contrast high culture with radicalised popular culture. Regarding the latter, they criticised attempts at erasing lines between art and life, and applauded art's autonomy, its apolitical and aesthetic essence. However, even in the landscape of Estonian art, discussions and attention centred around subjects characteristic of the West, such as socio-critical topics, and modern art mediums (installation, video, and virtual art, etc.). And in 1991, art historian and current rector of the Estonian Academy of Arts Mart Kalm remarked that 'since the 1980s, art is centred around museums, whose importance has grown considerably, and it regards politics realistically. The global crisis of leftism in the 1980s steered the arts towards humanism, and therefore now the main concerns include AIDS, Jews, immigrants, homosexuality, and feminism. ${ }^{2}$ Of course, as these new themes and approaches suddenly achieved popularity, those that appreciate the more traditional art felt doubtful and hesitant, which deepened the uncertainty of cultural coherence.

21 Mart Kalm, “Art, Politics, and Multiculturalism”, Sirp, 29.11.1991, 9
In 1993, art historian Johannes Saar notes, 'Discussions have all but left the circle of professionals and almost reached the level of folk debates. Categorical opinions have been offered by art lovers as well as haters. Even some formerly timid cultural reporters and a few politicians have assumed a more commanding tone. Art seems topical and popular. The reason for that may lie in the sudden radicalisation of many art trends, and the tense relationships that accompany it..22

What could cause the splitting of the art world? Collapse of the former, and idealised, image of the Western art scene has been considered a possible reason for that. Before the 1990s, most of the information regarding international art came via print media and a large number of artists mimicked the Western-style avant-garde with the help of available art publications and journals, which basically meant that this information was locally constructed and by and large idealised. The disappearance of the formerly constructed image was possibly one of the reasons why discussions were punctuated with unreasoned conflicts - the new reality and freedom had not arrived together with expected Western-like success and world-wide fame; on the contrary, now everyone had to start over to achieve that.

In 1992, in the spirit of liberalisation, the Soros Centre for Contemporary Art (SCCA) was brought to life to support the culture and arts projects of the young. ${ }^{23}$ Art historian and the manager of the centre at the time Sirje Helme admitted that 'the role of organisations has changed: Estonian Artists' Association, state museums and galleries are having to contend with limited budgets and economic difficulties. Infrastructure for the market economy has not yet evolved. /---/ Artists do not know how to act, how to survive in the new commercial world. ${ }^{24}$ In the same article she invited artists and exhibitions to be more open, and open-minded. Therefore, in principle, this meant setting new criteria for the arts - involving the social side, developing new art forms that would counter traditional and conventional tastes in art. The last criterion was almost a silent

22 Johannes Saar, “Tulevik pole enam see, mis ta oli enne", Sirp, 30.04.1993, 8.

23 This was a foundation created by the Open Estonia Foundation, which is the oldest institution (Estonian Centre for Contemporary Art). Since 1999, the centre is the commissioner of the Estonian Pavilion at the Venice Biennale, among other things. See https://cca.ee/en [accessed on 20.05.2020].

24 Sirje Helme, “Sorose Kaasaegse Kunsti Eesti Keskus - mis see on?”, Sirp, 18.12.1992, 9. 
agreement, no one actually wanted to say it out loud. As a result this undermined the artists' unity and deepened the conflict between generations. Inevitably, it seemed that all aesthetic and ethical values that had hitherto defined art had collapsed totally.

\section{WAR OF THE ARTS}

In the first years of the newly independent Republic of Estonia the art scene was still governed by faith in the illusional art world of the West, where functioning systems guarantee exhibitions in good galleries, and the well-being and fame of the artists. The situation was somewhat paradoxical, with two clearly delineated processes occurring simultaneously in the art life: one was the speedy association with new mediums and modes of expression, the other the restoration of adequate representation of Estonian art of the post-war era, which needed clear definition and meaning in the new circumstances. An important part of the latter were retrospective exhibitions in the 1990s. The goal was to stress the role and importance of former art in the preservation of national identity, and to restore previous artistic endeavours to the conscious history of the now independent republic. It was by the mid-1990s that the debates in the art world truly heated up.

The first serious polemics whirled around the status of painting. At the start of the 1990s, installation and video art began developing rapidly. These art forms were funded by many foundations, and enjoyed the critics' attention, which created a belief that nobody cared any more about the traditional painting (from the famous Estonian art school); and that situation has been referred to as the installations war against painting. Painter Vano Allsalu criticized his contemporaries in the newspaper Sirp (Sickle) in 1993: 'I believe that most of those that are interested in art, know by now that: everything is allowed in art, everything can be called art - whether they like it or not. /---/ Art is becoming part of showbusiness; indeed, it is made mostly by critics and not artists. However, unlike with Hollywood films, it does not matter whether housewives or schoolboys love it. On the contrary, the less mere mortals understand, the better. ${ }^{25}$

25 Vano Allsalu, "Mida sa kunstis ka ei teeks, kõige tähtsam on veenvus", Sirp, 23.04.1993, 9
On 20 November 1992, annual autumn exhibition opened at Tallinn Art Hall. Of course, everybody wanted to participate and the jury had to choose between works by 157 artists. Only 62 authors made it to the exhibition, excluding many acclaimed artists, which led to a 'civil war' on the capital's art scene. Art critic and artist Raivo Kelomees commented on the situation: 'it is undoubtedly a demonstration of tensions and power relations. The exhibition also shows who is at the pump and kicking those that are not there yet. But this shows that no matter who has the power, they will never be accepted absolutely. /---/ We must add that the layout plan has occurred over 'dead bodies', i.e. at the expense of neglected pieces and by disobeying unwritten rules. In this, despite everything, lies the exhibition's only justification. To be controversial, provocative - this is in linked to being interesting. And the latter is of paramount importance in art and exhibitions. ${ }^{26}$ In 1993, art critic Johannes Saar remarked on Estonian art life: 'every art event or comment on one is directed towards conflict, submission, denial of others. /---/ In general, the situation on the Estonian art scene can be described as a phenomenon that to greater or lesser extent has hit all of the former eastern bloc countries - 'cultural hysteria'. The former socialist countries are facing the fact that almost all of their cultural models stem from the 1920s, or even earlier times. More drama is added by the fact that this revelation only happened at the end of the century. ${ }^{27}$ As a result, in the 1990s Estonian contemporary art went rapidly and turbulently through the same stages of development which had occurred in the West over decades.

The Estonian SCCA $3^{\text {rd }}$ annual exhibition Biotoopia (combination of biology, technology, utopia) in 1995 was greeted with searing reactions. In the foreword to the exhibition catalogue Sirje Helme wrote: 'We cannot ignore the changing world. We cannot mechanically project the conceptions from relatively static cultures into the new realities that are being constructed. ${ }^{28}$ The exhibition was received with resentment, confusion, and praise at the same time, by both art critics and artists. No matter how politely the debate was framed in

26 Raivo Kelomees, "Kultuurirevolutsioon kunstihoone. Sügisnäitus - Eesti kunst murrangulisel ajajärgul", Postimees, 12.12.1992, 4

27 Johannes Saar, "Tulevik pole enam see, mis ta oli enne", Sirp, 30.04.1993, 8.

28 Sirje Helme, "Foreword", Biotoopia. Catalogue (Tallinn: Sorose Kaasaegse Kunsti Eest Keskus, 1996) 
newspapers, its essence remained simple - if modern art is lacking value categories and aesthetic principles, then can we even talk about ethics with regard to art that focusses on social messages? What is the meaning of art if it does not comply with universal values any longer. If we consider the exhibition as a symbol of its time, then it was a remarkable project. Firstly, it paved the way to the new media art in Estonia which really challenged the traditional art forms that had been steadily superior until then. Secondly, Biotoopia was an attempt to create a mental bridge between the local art scene and the world by dealing with the same subjects and polemics that the Western societies were facing. The only problem was that the Estonian art audience was not ready for that - most of the issues raised at the exhibition (relationship between technology and biology, etc.) were too unfamiliar, considering that most people in Estonia did not even have a computer at home back then.

The second noteworthy wave of discussions and conflicts revolved around art as a socio-critical medium. The previously asocial art now assumed a new position in which artistic aspirations were secondary to being socially astute. This can be explained by social theories making their way over here from the West, as well as by a change in general mentality: in the first half of the 1990s, when 'selfidentification' acquired a new meaning, individual self-image and gender- or sexuality-based self-identification gained prominence in art. Many exhibitions were organised on this theme, e.g. the international nude art exhibition Man and Woman opened in 1994 (and it became an annual tradition). 1995 can be viewed as a period where the meaning of feminist art and the influence of gender roles on artist's consciousness were debated in the Estonian art world in more depth, and critically, as the exhibition Est.Fem. opened in Tallinn. The efforts to manifest the need for feminist movement and to express that in art were cause for much conversation and created many substantial opinion pieces. An outstanding dialogue emerged between cultural historian Linnar Priimägi and one of the curators of the Est.Fem. exhibition Eha Komissarov. 'To create art for 'just women' or 'just men', 'women's art' or 'men's art', 'feminist' or 'masculinist' art is always narrowing, always tendentious, always ideological, and therefore hardly reconcilable with the essence of art. To be sure, the essence of art is to discover in a concrete person something that might be considered universally human. /---/ If art is

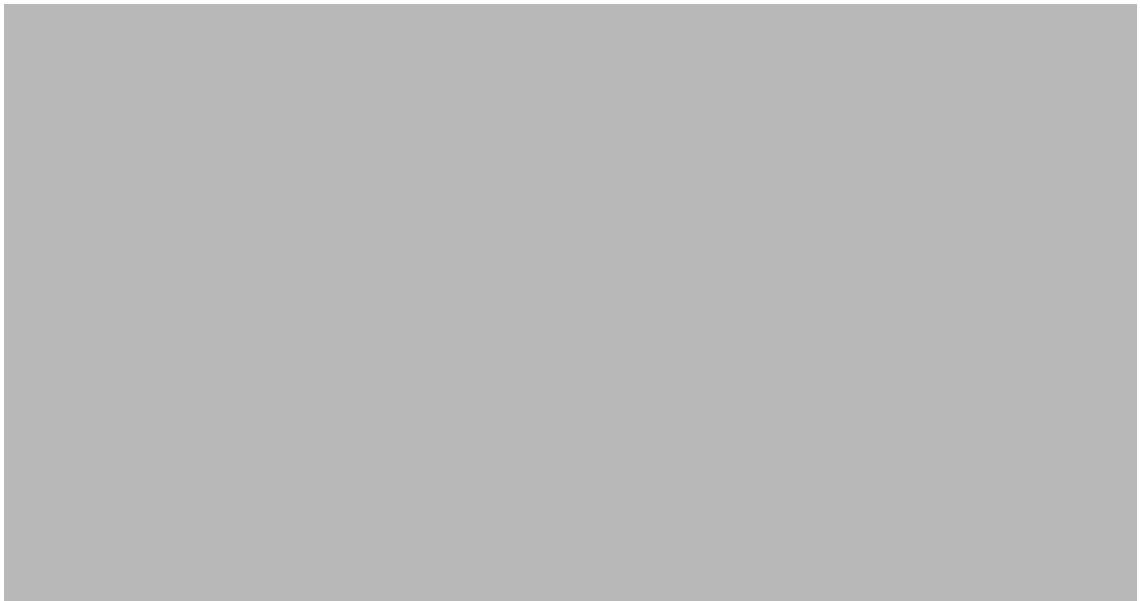

FIG. 1. RAUL MEEL, APOCRYPHAS (1997). ART MUSEUM OF ESTONIA.

art, it is not so because the author is a man or a woman, it is because the author is an artist, ${ }^{29}$ Priimägi wrote. Eha Komissarov called that 'a classic old-fashioned antifeminist opinion,' and remarked that the arts audience must 'accept that traditionally clean, visually pleasing aesthetics are restricted by the impure and problematised modern times, for whom some abstract universal artistic identity is absolutely not enough. ${ }^{\prime 30}$ It seems that while in the West feminist art was enjoying its second or third coming, in Estonia it was still infantile, and in art this manifested in confusion, without clear philosophical or theoretical background.

There are some outstanding cases that challenge aesthetic categories and ways of interpretation. Some of the more intriguing examples of the art of the last decade of the past century are Jaan Toomik's installation 15 May-1 June 1992 (consisting of glass jars filled with the artist's daily excrements during that period), and Raul Meel's series Apokriivad (Apocryphas) from 1997 (national flags painted on boards with controversial texts on them). First of those

29 Linnar Priimägi, ““Feministlikust” kunstist”, Eesti Päevaleht, 26.08.1995, 5.

30 Eha Komissarov, "Feminismist, nagu on", Eesti Ekspress, 22.09.1995, B4. 


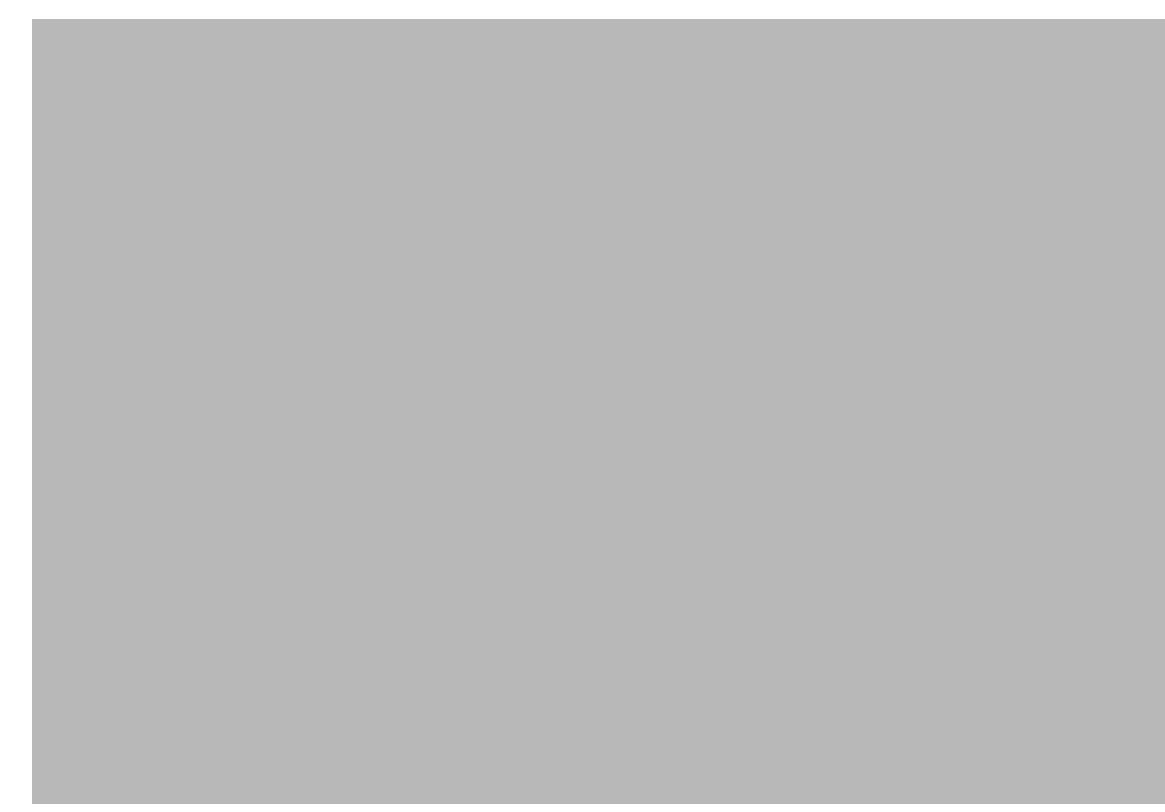

FIG. 2. MART VILJUS, ANIMAL (1995). EXHIBITION BIOTOOPIA. PHOTO: ESTONIAN CENTRE FOR CONTEMPORARY ART.



FIG. 3. TIINA TAMMETALU, UNTITLED (1995). EXHIBITION BIOTOOPIA. PHOTO: ESTONIAN CENTRE FOR CONTEMPORARY ART.

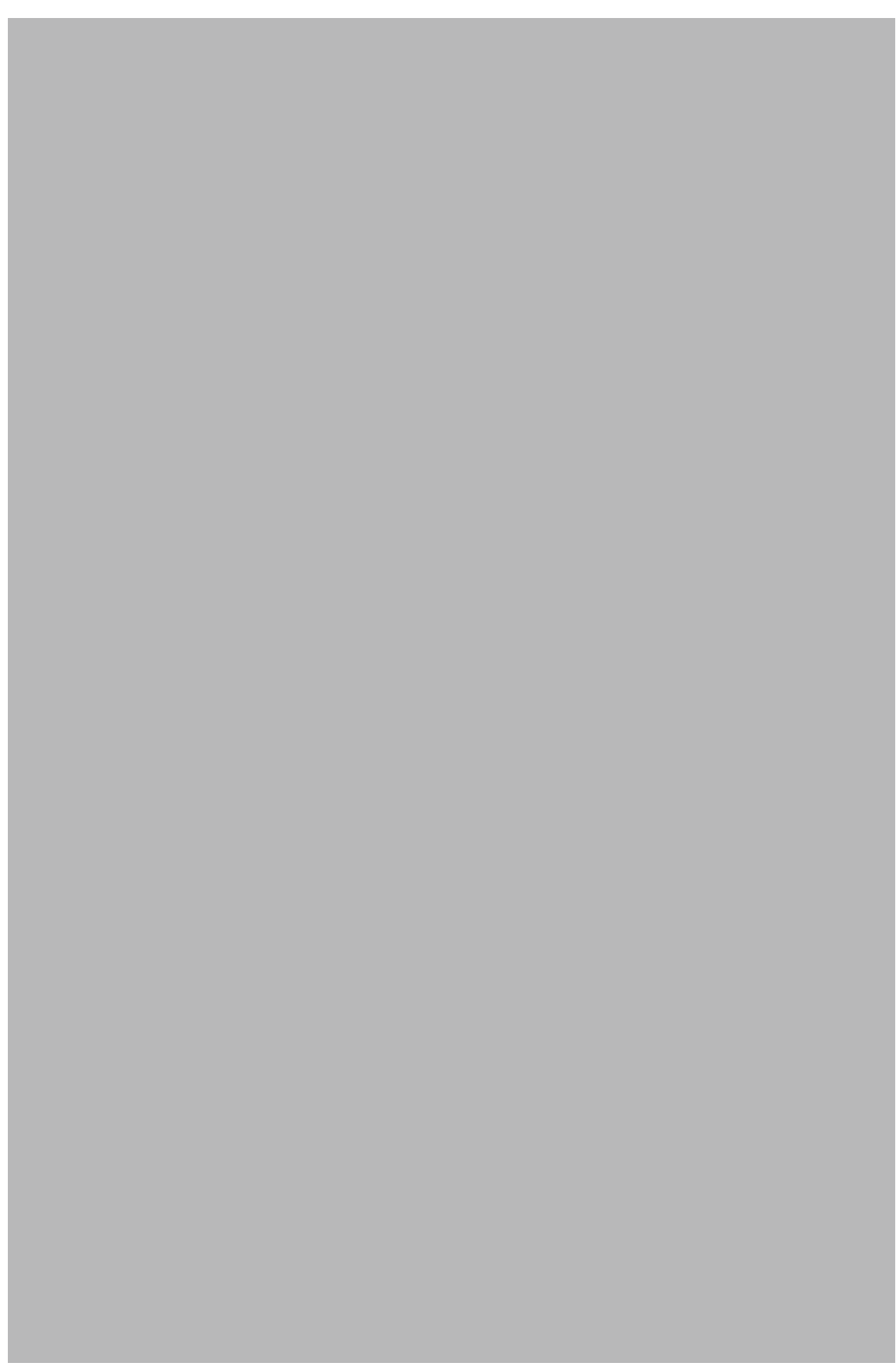

FIG. 4. ENE-LIIS SEMPER, PHOTO FROM THE SLIDE-INSTALLATION MUTANT À LA CARTE (1995), EXHIBITION BIOTOOPIA. PHOTO: DESTUDIO/ESTONIAN CENTRE FOR CONTEMPORARY ART. 
causes art theorists even today, two decades later, to argue over the ontological prerequisites and goals of art, and this makes us concede that perhaps in our contemporary culture there is no other field whose position is as uncertain as that of contemporary art. ${ }^{31}$ The second of the aforementioned examples ended up under investigation by the authorities in 1998, to ascertain whether it was tarnishing the national flag: it was not. Thus we can say that in the 1990s there was a kind of cultural war taking place in Estonia, where the more radical liberalism was opposed by conservative attitudes, mainly by artists (e.g. Jüri Arrak, Olev Subbi, Toomas Vint etc.). In 1995, Vint writes that 'now we have declared void all values that the term 'art' used to contain. But why then do we still teach drawing and painting in art schools?'32 In 1998, artist Jüri Arrak was feeling pessimistic at the plenum of Estonian Artists' Association: 'It seems that cursing and porn are in sync with the zeitgeist and most people follow trends and currents, even if it is in the sewers, because once you close your nose, mouth, and eyes, it is lovely to slide down some warm shit! The life of a trend artist is hard, because if the next trend is murder, do you grab an axe instead of a word or picture, because the supressed urge to kill needs a 'cultural' outlet and appreciation. ${ }^{\prime 33}$

In 1960, French Catholic philosopher Jacques Maritain considered art's relationship with society in The Responsibility of the Artist. Among other things he names three important factors that determine general tastes in art: (a) collective consciousness and public opinion founded on national ethos; (b) larger groups of citizens who warn others of certain works of art, books, and films; (c) private organisations and unions that bind either consumers of culture, or authors, critics, etc. According to Maritain, it is the society (not the state) that assumes responsibility for protecting humanity from dangerous works. ${ }^{34}$

In principle, this approach suits the contemporary democratic government: on the one hand, artists have creative freedom, but as members of society they are also responsible for the content and form of their work; on the other hand, the arts audience is free to choose

31 Marek Tamm, "Kaasaegse kunsti paradoksid", Postimees, 22.09.2012.

32 Toomas Vint, "Huvitav liigisisene tõuaretus", Eesti Päevaleht, 22.12.1995.

33 Jüri Arrak, "Valikuvabadusest", Võsa, aas ja mägi (Tartu: Ilmamaa, 2003), 49.

34 Jacques Maritain, Kunstniku vastutus (Tartu: Ilmamaa, 2012), 67. which book to read or which exhibition to see, whilst maintaining their critical faculties and respecting universal values.

A kind of culture war took place in Estonia in the 1990s, where liberal attitudes were confronted by some more conservative views. However, the intense debates over content and form of the arts remained short-lived, as on the fast track to liberalisation new western trends were quickly appropriated and opposing voices were rather swiftly silenced. The latter was aided by the euphoria caused by freedom from Soviet-style censorship and surveillance, and therefore those that did not follow changes quickly enough were ridiculed and considered incompetent. In the following decades, these kinds of conflicts have mostly manifested as tiffs within institutions, such as arguments around museums' programmes and management policies; however, there is a lack of serious theoretical and intellectual discussion to define the meaning of contemporary art in history.

\section{CULTURAL JOURNALISM}

In today's western societies freedom is usually considered one of the primary human rights; however, the liberal cultural space does carry within it certain contradictions. Firstly, the term 'freedom' is in itself rather abstract - it is difficult to find a clear definition or understanding of its norms. Its meanings are manifold, and they vary according to people's cultural and historical backgrounds. Secondly, both religious and political affiliations can define freedoms of speech creativity, and expression, their rigidity or flexibility. Thirdly, it is clear that sooner or later social order or disorder must be regulated at a governmental level, even if it means limiting the freedoms of some groups or individuals. This exposes the paradox of freedom it is kind of a closed circle - an ideal in a free society, but apparently unable to function without conflict. At least as long as there exists pluralism of thought and conviction.

A political regime cannot be legal if its central social goals have not been agreed upon by both the rulers and the subjects. In Estonian journalism up until the 1980s there was a strong discord between the government and local intellectuals. It was not just about the content of journalism, but also the prioritisation of topics. Estonian media theorist and journalist Maarja Lõhmus has identified three stages in the development of Estonian public writing in 1980-1990: it was 
mostly totalitarian until 1987-1988, then until the beginning of the 1990s it was participative, and from there on liberal/democratic. The latter is characterised by the theoretical possibility that all thoughts and suggestions can be made public. ${ }^{35}$

In fact, changes in the Estonian art world started in the mid-1980s, when heritage protection became a hot topic - on the one side there were powerful defenders of historical and archaeological monuments, and on the other side intellectuals with somewhat more progressive views, who saw the potential of historical monuments to be useful to national culture, to bind history to today and to give new function to monuments left idle in the Soviet era (e.g. theatres, galleries, etc.). ${ }^{36}$ The joint plenum of creative associations in 1988 was a remarkable and decisive event. ${ }^{37}$ Speeches at that plenum proclaimed de facto no confidence in the Estonian SSR's political administration - they insisted that creative censorship in the state must be abolished completely, and absolute freedom of speech and expression must be mandated. For example, artist Jüri Arrak declared in his speech: 'I am so glad I got to live to this day when in this hall we can speak candidly about problems that in recent past would have sent us to prison. ${ }^{38}$ We could say that the same year journalism in all three Baltic states had broken free from government control. ${ }^{39}$ The so-called singing revolution of 1988-1991 dominated journalism; and environmental, political, and nationalist topics came to the fore. From 1991 onward the focus was mainly on economy and political institutions..$^{40}$ The new circumstances of the 1990s led to ever greater numbers of newspapers and periodicals in Estonia. Research has shown that even in the 1980s

35 Maarja Lõhmus, "Avalik tekst ja Nõukogude repressiivne avalik tekst", Keel ja Kirjandus, 2 (2003), 92-100.

36 See e.g. Juhan Maiste, "Ajalooline Tallinn - kas sfinksimõistatus? Kriitilisest ja kunstilisest restaureerimisest", Sirp ja Vasar, 18.03.1988, 8 .

37 The joint plenum of leaders of Estonian SSR's creative associations took place in 1-2 Supreme Soviet of Estonian SSR. The official reasen for the assembly was to discuss the creative associations' part in the decisions of the XXVII Congress of the Communist Party of the Sovie Union, and preparations for the XIX pan-Union Party Conference. The plenum was opened by the Theatre Association's chairman Mikk Mikiver. Overall, there were 58 speeches from 55 speakers. 38 Eesti NSV loominguliste liitude juhatuste ühispleenum 1.-2. aprill 1988, comp. by Mall 38 Eesti NSV loominguliste liitude juhat

õgi (Tallinn: Eesti Raamat, 1988), 36 (4) (1993), 359

$40 \quad$ Ibidem, 357-359.
Estonians always respected subscribing to and reading periodicals, compared to the rest of Europe. For example, in 1984, an average adult Estonian read three to four periodicals, to which they also held subscriptions. ${ }^{41}$ In 1988-1991 more than 400 new journals or periodicals arrived on the scene. First independent weekly newspapers with broad readerships appeared in autumn 1989. In 1992, the first independent and autonomous daily newspaper was published. ${ }^{42}$ Based on this, there is no doubt in the importance of journalism as the provider of cultural platforms and voice.

In 1993, an interesting situation occurred in Estonian cultural journalism, when tensions flared between journalists and art historians and critics. The reason - representations of contemporary art in media, which did not meet the art critics' expectations. In the spring of that year, art critics and journalists met at the Soros Centre for Contemporary Art for an information hour with the goal to better 'the journalistic response to art, driven by the critics' dissatisfaction with the coverage of contemporary art exhibitions thus far. ${ }^{\prime 43}$ That meeting exposed sharp contrasts of expectations and attitudes, and journalists felt like they were being lambasted the meeting which could have resulted in concrete agreements turned into debates over art forms, where art critics expressed their long-standing concerns. At times, it was funny; for example: critics expect journals to dedicate lots of space to articles by professionals, while it quickly transpires that they are all too busy to write them.'44 Journalist Tiina Käesel takes an even more critical look at the strange situation: 'So now the leading art critics and dealers have assembled arts journalists. Anyway, this brought to mind something familiar: not so long ago (but long enough for the younger colleagues not to know anything about it) they used to invite art editors to the Artists' Association to 'discuss' in front of management and representatives of sections the published (and especially not yet published, ordered, or advertised) articles. Now the journalists were accused: art critique is unprofessional, there is a lot of tendentiousness in journalism,

41 Marju Lauristin, Peeter Vihalemm, Sulev Uus, Juhan Peegel, Rajoonileht ja lugeja (Tallinn Eesti Raamat, 1987), 89-91.

42 Lagerspetz, "Social Problems in Estonian Mass Media 1975-1991", 360.

43 Aita Kivi, Tõnu Seero, "Ajakirjandus ja kunstikriitika”, Rahva Hääl, 22.05.1993, 5.

44 Ibidem. 
progressive art trends are misrepresented, the tramples on local young, fragile art experimentation seem almost organised. (What can you do when everyone is so uncultivated.) Educate yourselves, read, travel - they kindly suggested. /---/ If a journalist must be like a DJ, spinning the currently popular records, then it is not the fault of the journalist if they have no records to spin. ${ }^{.45}$

Today, with a couple of decades' hindsight, I can describe the 1990s as the decade of search for an enemy. There were those that saw the new enemy in active internationalisation, for some it was the new generation who started creating new artistic languages according to their individualist world view, and there were those who regarded the traditionalist intellectuals or the state as the hindering factors unable to build new market-based support systems fast enough.

\section{CONCLUSION}

The 1990s in Estonia are viewed as a period of transitional culture, or more broadly as part of the post-Socialist sphere that is characterised by Western aspirations. In reality, behind the apparent success story and freedom belie extremely difficult years which brought with them intellectual tensions on top of economic hardship. Democratisation process consciously followed the Western mentality and neoliberalism; however, this was concurrent with a certain distancing from national cultural self-identity, and a diminished understanding of Estonian national art. Liberal democracy is known for its ideological differences and competition, which stand in the way of shared interpretations of cultural self-identification. Its artistic expressions aided Estonia's acceptance into the Western world, but deepened schisms between local artists and intellectuals. Nonetheless, it is hard to underestimate the intellectuals' role as spokespeople in the 1980s, when their united actions created a significant foundation for the Estonian Restoration of Independence, which also allows us to draw a straight parallel with the Estonian national awakening period at the end of the $19^{\text {th }}$ century. The intellectuals possessed an authority that was needed to express views opposing the official ideology. We can assert that in 19881991 the arts and culture were the foremost drivers of political and social progress, and cultural journalism was an important platform for communication.

The problematic and often controversial 1990s are an example of a cultural circumstances where the external enemy disappears and freedom is won, which in many ways meant starting from scratch - all doors were open and everything seemed possible. The cultural elite, who had hitherto stood centre stage, were now increasingly in the background, and the economic and political elite rose to prominence. As the capitalist world dictates, instead of common cultural identity, individualistic success and materialism now became important.

It is true that in the 1990s there occurred a certain distancing from national self-identification. This is explained by necessity (sense of unity was central during the collapse of the Soviet bloc, but in the new circumstances it remained in the background), as well as confusion (adjusting the local cultural situation to developments in Western countries). In conclusion, the cultural changes in Estonia in the 1990s were classic phenomena of transitional society, whose influences are felt even today. Many erstwhile negations have become today's affirmations, and topics that seemed radical rarely cause strong reactions; however, we must not forget that the bigger the freedom of expression protected by democracy, the bigger the chances of conflicts between differing opinions and ideas. Especially when it comes to the aesthetic and ethical criteria for works of art. Immanuel Kant wrote about a naïve bird who, flying against wind, was dreaming of windless space where no breeze would hamper its flight; of course it did not understand that in a vacuum it would simply drop down dead. Contemporary liberal cultural circumstances are often thought of along similar lines, by supposing that the antagonisms of the art world have now been eradicated, that everything is allowed and there are no obstructions. Reality is a little different, of course. The need to define, justify, and defend one's views has not disappeared, if anything, it is stronger than ever. 
KADR I ASMeR: The Decade of Great Myths: Developments on the Estonian Art Scene in the 1990s

KEYWORDS: Estonian art; 1990s; EAstern Europe; Estonian CULTURAL POLICY; TRANSITIONAL CULTURE

\section{SUMMARY}

Estonian art life changed radically at the beginning of 1990s, especially with regards to organisational and financial systems. In other words, the collapse of the Soviet cultural system was followed by strong shifts that brought with them changes, in both content and form, within the arts and the institutional mechanisms.

This article maps out some of the most notable developmental tendencies that began taking shape after the restoration of independence, for example the meaning of art and the role of cultural journalism and art critique in the new reality. Even though the focus of the text is on Estonia, the changes that took place in the cultural sphere of the 1990s were not location-specific as similar trends existed more or less in all former republics of the Soviet Union.

\section{CV}

Kadri Asmer is a lecturer and editor in the Department of Art History at the University of Tartu. Asmer has compiled several anthologies including: Armin Tuulse, Linnad ja lossid (2013); Indrek Hirv, Tartust Pariisi ja tagasi (2016); Juhan Maiste, Vabadus mäletada (2016); In Search of the University Landscape: The Age of the Enlightenment (with Juhan Maiste, 2018). While her research focuses mainly on $20^{\text {th }}$ century art history, she is especially interested in cultural politics from the 1950s to the present in the United States and Europe. In addition to her academic work, she curates exhibitions and writes art reviews. 